\title{
Financial Crisis and its Asymmetric Macroeconomic Impact on Eurozone Member Countries
}

\author{
Lubor Lacina, Antonín Rusek
}

April 22 - 23, 2010

Wroclaw 


\section{Motivation}

- Eurozone enlargement by NMS - ongoing political discussion how far or slow process - recommendations for policy makers

- Role of Germany during 1992 - 3 EMS crisis and recent role of Germany

- Recent crisis of eurozone - Forbidden topic - the problem will be not solved if we are not talking about its existence 


\section{Aim of the paper}

- The purpose of this paper is to analyze the dynamics of EMU (The Economic and Monetary Union, i.e. the group of European countries who use the common currency Euro) and to discuss the possible alternative futures for EMU in a wake of the ongoing world wide financial difficulties and economic recession. 
Figure 1: Three Possible Scenarios for the Development of Potential Product in the Eurozone

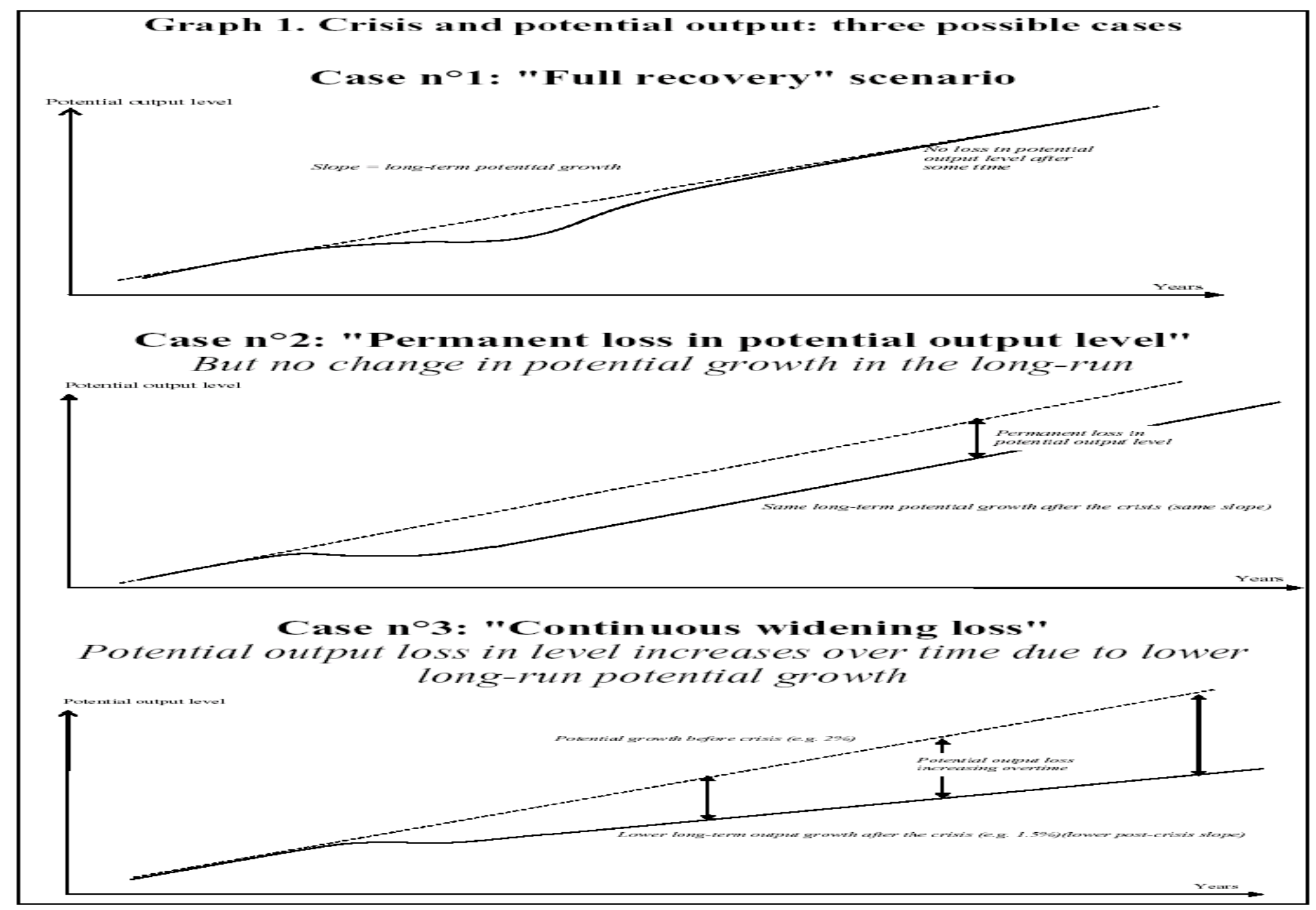

Source: Koopman, G.J., Székely, I.P. (2009) 
TABLE 1 - GDP, UNEMPLOYMENT, INFLATION: 1999:Q1 - 2008:Q1

\begin{tabular}{|l|c|c|c|c|}
\hline & \multirow{2}{*}{$\begin{array}{c}\text { Annualized Average } \\
\text { Quarterly GDP growth }\end{array}$} & Unemployment Rate & \multirow{2}{*}{$\begin{array}{c}\text { Annualized Average } \\
\text { Monthly CPI Inflation }\end{array}$} \\
\cline { 3 - 4 } Eurozone (EU12) & 2.26 & $1999: \mathrm{Q} 1$ & $2008: \mathrm{Q} 1$ & 2.10 \\
\hline Total EU & 2.46 & 9.5 & 7.2 & 2.04 \\
\hline & & 9.5 & 6.7 & 2.04 \\
\hline Belgium & 2.30 & & 6.9 & 1.61 \\
\hline Germany & 1.77 & 9.0 & 7.6 & 3.39 \\
\hline Ireland & 6.55 & 8.6 & 4.8 & 3.23 \\
\hline Greece & 4.14 & 6.3 & 7.8 & 3.18 \\
\hline Spain & 3.64 & 11.4 & 9.2 & 1.82 \\
\hline France & 2.17 & 13.3 & 7.6 & 2.32 \\
\hline Italy & 1.49 & 10.8 & 6.5 & 2.75 \\
\hline Luxembourg & 5.01 & 11.1 & 4.4 & 3.39 \\
\hline Netherlands & 2.54 & 2.4 & 2.8 & 1.79 \\
\hline Austria & 2.54 & 3.5 & 4.0 & 2.94 \\
\hline Portugal & 1.45 & 4.0 & 7.7 & 1.61 \\
\hline Finland & 3.28 & 4.6 & 6.3 & \\
\hline & & 10.6 & & 2.75 \\
\hline USA & 2.58 & 4.3 & 3.8 & -0.28 \\
\hline Japan & 1.60 & 4.7 & & \\
\hline
\end{tabular}


TABLE 2 - GDP, UNEMPLOYMENT, INFLATION: 2008:Q2 - 2009:Q3

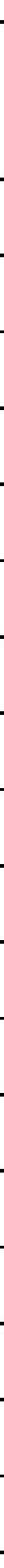


TABLE 3 - Competitiveness Indicators: 1999:Q1 - 2008:Q1

\begin{tabular}{|c|c|c|c|c|c|}
\hline & $\begin{array}{l}\text { Unit Labor Costs } \\
\text { (ULC) }\end{array}$ & $\begin{array}{l}\text { Real Effective } \\
\text { Exchange Rate (ULC } \\
\text { based) }\end{array}$ & $\begin{array}{l}\text { Real Effective } \\
\text { Exchange Rate (CPI } \\
\text { based) }\end{array}$ & Total Labor Costs & $\begin{array}{l}\text { Real Wages and } \\
\text { Salaries }\end{array}$ \\
\hline EU12 & & & 110.34 & 125.29 & 124.65 \\
\hline Total EU & & & & 133.83 & 133.74 \\
\hline Belgium & 115.84 & 103.66 & 105.04 & 128.27 & 128.87 \\
\hline Germany & 100.93 & 87.09 & 99.32 & 114.84 & 116.45 \\
\hline Ireland & 135.52 & 127.88 & 123.92 & N/A & N/A \\
\hline Greece & 124.21 & 112.09 & 108.86 & 132.80 & 132.33 \\
\hline Spain & 132.29 & 116.66 & 114.20 & 141.35 & 138.43 \\
\hline France & 117.35 & 104.17 & 102.08 & 131.27 & 129.39 \\
\hline Italy & 125.50 & 111.80 & 106.17 & 126.46 & 126.59 \\
\hline Luxamburg & 127.80 & 115.32 & 111.47 & 130.43 & 132.93 \\
\hline Netherlands & 119.12 & 109.17 & 107.57 & 134.82 & 129.60 \\
\hline Austria & 107.13 & 94.73 & 98.93 & 121.85 & 125.06 \\
\hline Portugal & N/A & N/A & 107.95 & 124.81 & 124.12 \\
\hline Finland & 114.69 & 100.89 & 101.19 & N/A & N/A \\
\hline USA & 104.80 & & 80.88 & & \\
\hline Japan & & & 77.85 & & \\
\hline
\end{tabular}


TABLE 4 - Competitiveness Indicators: 2008:Q1 - 2009:Q3

\begin{tabular}{|l|l|l|l|l|l}
\hline & $\begin{array}{l}\text { Unit Labor Costs } \\
(\text { ULC })\end{array}$ & $\begin{array}{l}\text { Real Effective } \\
\text { Exchange Rate } \\
\text { (ULC based })\end{array}$ & $\begin{array}{l}\text { Real Effective } \\
\text { Exchange Rate } \\
\text { (CPI based) }\end{array}$ & Total Labor Costs & $\begin{array}{l}\text { Real Wages and } \\
\text { Salaries }\end{array}$ \\
\hline EU12 & & & 92.98 & 103.75 & 103.65 \\
\hline Total EU & & & 101.61 & 101.21 \\
\hline Belgium & 107.23 & 101.34 & 99.87 & 104.90 & 104.38 \\
\hline Germany & 108.07 & 102.30 & 98.84 & 106.51 & 106.00 \\
\hline Ireland & 102.35 & 97.48 & 98.52 & N/A & N/A \\
\hline Greece & 108.34 & 99.39 & 100.70 & 98.71 & 97.43 \\
\hline Spain & 101.11 & 95.66 & 99.38 & 105.20 & 103.65 \\
\hline France & 104.63 & 98.69 & 98.93 & 99.60 & 99.80 \\
\hline Italy & 105.78 & 99.74 & 99.59 & 102.41 & 102.31 \\
\hline Luxamburg & 108.73 & 101.66 & 97.65 & 103.03 & 103.44 \\
\hline Netherlands & 107.01 & 99.93 & 99.48 & 100.70 & 101.81 \\
\hline Austria & 106.63 & 100.40 & 99.74 & 105.37 & 104.96 \\
\hline Portugal & N/A & N/A & 98.99 & 103.14 & 102.53 \\
\hline Finland & 111.36 & 104.57 & 101.66 & N/A & N/A \\
\hline USA & 106.20 & & 109.25 & & \\
\hline Japan & & & 107.75 & & \\
\hline
\end{tabular}


TABLE 5 -- Public Debt and Current Account

\begin{tabular}{|c|c|c|c|c|c|c|}
\hline & \multicolumn{3}{|c|}{$\begin{array}{l}\text { The Share of Public Debt in GDP } \\
\text { (in \%) }\end{array}$} & \multicolumn{3}{|c|}{$\begin{array}{l}\text { Current Account as the Share of GDP } \\
\text { (in \%) }\end{array}$} \\
\hline & 2000:Q1 & 2008:Q1 & 2009:Q2 & 1999:Q1 & 2008:Q1 & 2009:Q2 \\
\hline EU12 & 72.0 & 67.4 & 76.3 & & & \\
\hline Belgium & 116.0 & 87.8 & 96.7 & 5.44 & -1.46 & 4.13 \\
\hline Germany & 61.0 & 65.2 & 71.1 & -1.76 & 8.23 & 3.98 \\
\hline Ireland & 44.6 & 27.6 & 59.3 & 0.55 & -9.00 & -2.90 \\
\hline Greece & 115.5 & 96.5 & 109.4 & -3.65 & -14.51 & -11.31 \\
\hline Spain & 61.0 & 35.3 & 47.0 & -1.85 & -11.31 & -3.92 \\
\hline France & 57.7 & 65.3 & 73.9 & 3.01 & -0.98 & -2.90 \\
\hline Italy & 113.5 & 106.1 & 113.3 & 0.31 & -4.35 & -3.22 \\
\hline Netherland & 61.9 & 46.3 & 61.1 & 4.24 & 6.81 & 5.70 \\
\hline Luxemburg & 6.1 & 7.0 & 14.7 & 18.90 & 10.08 & -4.20 \\
\hline Austria & 70.7 & 61.3 & 68.7 & -0.07 & 7.31 & -0.24 \\
\hline Portugal & 52.8 & 62.6 & 74.1 & -7.07 & -9.81 & -8.44 \\
\hline Finland & 47.1 & 33.6 & 35.2 & 3.08 & 4.78 & -1.78 \\
\hline \multicolumn{7}{|l|}{ USA } \\
\hline Japan & & & & 2.07 & 5.08 & 2.10 \\
\hline
\end{tabular}




\begin{tabular}{|l|l|l|l|l|l}
\hline & \multicolumn{4}{l|}{$\begin{array}{l}\text { The Loan Dynamics - \% change } \\
\text { relative to base period }\end{array}$} & \multicolumn{2}{l}{ The Total Loans to GDP Ratios } \\
& $\begin{array}{l}2008: \mathrm{Q}- \\
1999: \mathrm{Q} 1\end{array}$ & $\begin{array}{l}2009: \mathrm{Q}- \\
2008: \mathrm{Q} 4\end{array}$ & $1999: \mathrm{Q} 1$ & $2008: \mathrm{Q} 4$ & $2009: \mathrm{Q}$ \\
\hline & & & & & \\
\hline Belgium & 75.87 & -2.78 & 583.97 & 667.20 & 700.77 \\
\hline Germany & 29.73 & -3.36 & 761.65 & 759.78 & 746.27 \\
\hline Ireland & 386.09 & -7.63 & 665.47 & 1509.78 & 1534.54 \\
\hline Greece & 198.84 & 3.49 & 320.87 & 439.73 & 443.32 \\
\hline Spain & 247.81 & -2.82 & 488.15 & 832.94 & 903.23 \\
\hline France & 92.56 & -1.40 & 613.14 & 791.51 & 830.17 \\
\hline Italy & 161.91 & -0.86 & 355.55 & 608.12 & 650.47 \\
\hline Netherland & 91.35 & 0.98 & 672.93 & 780.41 & 886.97 \\
\hline Luxemburg & 86.82 & -13.42 & 5919.87 & 5235.80 & 4880.92 \\
\hline Austria & 103.14 & -1.21 & 662.18 & 881.63 & 892.53 \\
\hline Portugal & 133.80 & 0.13 & 530.31 & 777.39 & 806.50 \\
\hline Finland & 182.59 & -1.88 & 233.94 & 396.54 & 441.01 \\
\hline & & & & & \\
\hline
\end{tabular}




\section{Scenarios of the Future}

- Future, especially in the realm of national (and transnational) economies is always difficult to predict even when such predictions are the sine qua non for the both general and economic policies. The reasons are that modern economies (and societies) are not only the interplay of the rational market forces (bread and butter of economic modelling) but are affected by a variety of, social political and generally random factors. These are generally unpredictable, often even for the participating actors. Hence, anytime an analysis pertaining the future is contemplated, it pays to specify some basic assumptions. 


\section{Assumptions for scenarios of the future (1)}

- Firstly, as has been true of economic crises in the past, it may be presumed that this crisis, too, will be connected to a slowdown in the integration process and the growth of "eurodecentralization" tendencies within the individual member countries 


\section{Assumptions for scenarios of the future (2)}

- The second important presupposition which must be taken into account with all of the envisioned scenarios is the nonexistence of legislation (a precedent) under which a country may exit the eurozone. 


\section{Assumptions for scenarios of the}

\section{future (3)}

- The third point which fundamentally impacts how well the scenarios presented conform to reality is the fact that any withdrawal of the country from the eurozone would likely lead to a deepening of economic problems for the economy in question instead of an immediate improvement in the country's situation. 


\section{Scenarios of the Future (1)}

- Scenario 1: The current crisis is successfully overcome in the eurozone expands further

- Sub-scenario 1a: Rapid expansion of the eurozone without requiring fulfilment of the convergence criteria, using a "halfway membership" status for new eurozone member countries

- Sub-scenario 1b: Unilateral euroization 


\section{Scenarios of the Future (2)}

- Scenario 2: Collapse of the eurozone in its existing form and the creation of a new monetary union featuring countries which have traditionally pegged their currency to Germany's and countries with a substantial amount of foreign trade with Germany - a socalled "markozone"

- Scenario 3: Collapse of the eurozone and a return to national currencies

- Other alternatives 


\section{Literature}

-

(1)

Čsú (2009): Deflace. Czech Statistical Office. (online). http://www.czso.cz/csu/redakce.nsf/i/deflace Dvořák, P. (2008): Veřejné finance, fiskální nerovnováha a finanční krize. 1st edition Prague C.H. Beck. (2008). 343 pp. ISBN: 978-80-7400-075-1.

EC (2008): EMU@10: Successes and Challenges after 10 years of Economic and Monetary Union. EUROPEAN ECONOMY. 2. June 2008. Brussels. 342 pp. (online).

http://ec.europa.eu/economy finance/publications/publication12682 en.pdf

EC (2009): The EU's response to support the real economy during the economic crisis: an overview of Member States' recovery measures. EUROPEAN ECONOMY.

Euractiv (2004): Pařiž a Řím proti nezávis/osti. (online). http://www.euractiv.cz/ekonomika-a-euro/clanek/pa-am-proti-nezvislosti-ecb

Euroskop (2009): Plán hospodářské obnovy. (online). http://www.euroskop.cz/8439/9804/clanek/planhospodarske-obnovyl

Euractiv (2007): Sarkozy under fire for renewed ECB criticism. 17 September 2007. (online)

http://www.euractiv.com/en/euro/sarkozy-fire-renewed-ecb-criticism/article-166769

Eurostat (2009): Euro area inflation estimated at -0.1\%. Eurostat Newsreleases Indicators, 96/2009. 30 June 2009. (online). http://epp.eurostat.ec.europa.eu/cache/ITY PUBLIC/2-30062009-AP/EN/2-30062009-APEN.PDF

Guardian (2005): The Euro has Screwed Everybody - Berlusconi. Guardian. 27 July 2005. (online). http://www.guardian.co.uk/world/2005/jul/29/euro.italy

HN (2009): Recept MMF: poloviční členství v eurozóně. 7 April 2009. 7 April 2009. [online]. [cit. 2009-08-30] <http://hn.ihned.cz/c1-36646210-recept-mmf-polovicni-clenstvi-v-eurozone>

Kapounek, S., Přenosil, J. Evropská centrální banka a její monetární politika. In Lacina, L. et al. In Lacina, L. et al. Měnová integrace: náklady a př́nosy členství v měnové unii. Prague. C.H.Beck. pp. $303-361$. ISBN: 978-80-7179-560-5

Klaus, V. (2003): Euro a jeho budoucnost: pohled z budoucí členské země. Lecture at the CATO Institute, Washington D.C., 20 November 2003. (online). Available at: http://cepin.cz/docs/newslettery/2004-01.pdf 


\section{Literature (continue)}

- Koopman, G.J., Székely, I.P. (2009): The Financial Crisis and Potential Growth: Policy Challanges for Europe. Directorate-General for Economic and Financial Affairs. Issue 3 | June 2009. ECFIN Economic Brief. (online) http://ec.europa.eu/economy finance/publications/publication15519 en.pdf

- $\quad$ König, P. , Lacina, L., Přenosil, J. Učebnice evropské integrace. Second updated and expanded edition. Brno: Barrister \& Principal, 2007. 402 pp. ISBN: 978-80-7364-044-6

- $\quad$ Pisani-Ferry, J., Ph. Aghion, M. Belka, J. von Hagen, L. Heikensten and André Sapir and A. Ahearne (rapporteur) (2008): Coming of Age: Report on the Euro Area. Bruegel Blueprint, 4. (online). http://aei.pitt.edu/8337/01/bruegel comingofage.pdf

- $\quad$ Pisani-Ferry, J. (2009): The good and the bad flexibility. Bruegel Think Tank. June 2009. (online).

http://www.bruegel.org/uploads/tx btbbreugel/JPF Le Monde Flexibility Pisani EN.pdf

- $\quad$ Pritchard-Evans, A: Germany's slump risks 'explosive' mood as second banking crisis looms. Telegraph online. 23. April 2009. (online).

http://www.telegraph.co.uk/finance/financetopics/financialcrisis/5209033/Germanys-slumprisks-explosive-mood-as-second-banking-crisis-looms.html

Rusek, A. (2007). Přežije eurozóna (a Evropská unie) rok 2010? (úvaha o „zakázaném“ tématu). in Lacina, L. - Rusek, A. Eds.). Evropská unie: přiležitosti, výzvy, rizika. Plzeň: Aleš Čeněk Publishing, 2007, pp. 57 - 78. ISBN: 978-80-7380-077-2 


\title{
Questions, comments?
}

Contacts:

\author{
Mendel University in Brno, Czech \\ Republic, e-mail: lacina@mendelu.cz \\ Susquehanna University, USA, e-mail: \\ rusek@susqu.edu
}

